Provided by the author(s) and University of Galway in accordance with publisher policies. Please cite the published version when available.

\begin{tabular}{|c|l|}
\hline Title & Bilateral FDI and Canadian Export Activity \\
\hline Author(s) & Mullen, John K. \\
\hline $\begin{array}{c}\text { Publication } \\
\text { Date }\end{array}$ & 2010 \\
\hline $\begin{array}{c}\text { Publication } \\
\text { Information }\end{array}$ & $\begin{array}{l}\text { Mullen, J.K. \& Williams, M. (2010) Bilateral FDI and } \\
\text { Department of Economics, National University of Ireland, } \\
\text { Galway. }\end{array}$ \\
\hline Publisher & National University of Ireland, Galway \\
\hline Item record & http://hdl.handle.net/10379/1447 \\
\hline
\end{tabular}

Downloaded 2023-04-26T04:54:19Z

Some rights reserved. For more information, please see the item record link above. 


\title{
Bilateral FDI and Canadian Export Activity
}

\author{
John K. Mullen* \& Martin Williams** \\ Working Paper No. 0161 \\ April 2010 \\ Department of Economics \\ National University of Ireland, Galway \\ http://www.economics.nuigalway.ie
}

*John K. Mullen' c/o School of Business, Clarkson University, Potsdam, NY 13699 and

**Martin Williams, Department of Economics, Northern Illinois University, DeKalb, Il 60115 


\begin{abstract}
This study examines how Canadian exports to a specific trading partner are influenced by outward and inward direct investment flows to/from that country. A gravity-type empirical model guides a dynamic panel analysis which utilizes OECD country-level data from 1989-2007. Besides refuting the contention that outward FDI displaces exports, the findings also imply a strong role for intra-firm based export growth in response to inward FDI. The analysis is enriched by explicitly accounting for the dominant position of the U.S. within the context of Canada's overall trade and investment flows.
\end{abstract}

*This research has been supported in part by an award from the Canadian Embassy's Faculty Research Grant Program, 2004-05. The viewpoints presented herein are ours alone, and we remain solely responsible for any errors.

${ }^{* *}$ Corresponding author (email: mullenj@clarkson.edu; phone: 315-268-4283; fax: 315268-3810; mailing address: c/o CUSB, Box 5785, Clarkson University, Potsdam, NY 13699 USA) 


\section{INTRODUCTION}

The integration of the world's developed economies has been manifested, in part, by a dramatic rise in foreign direct investment (FDI) by multinational corporations. At the same time, the rapid growth in the volume of trade has led to a renewed interest in the relationship between exports and foreign production. Traditional trade models have generally treated exports and outward FDI as competing ways of serving foreign markets, implying a degree of substitution between these two activities. A long-held view is that investment abroad constitutes a "tariff-jumping" activity that benefits multinational firms even as it displaces export activity. Yet the empirical evidence often demonstrates a complementary relationship, suggesting the importance of vertical production in general and intra-firm trade in particular (e.g., see Head and Ries, 2001). The overall relationship between foreign production and trade remains a complex one however, and is likely to vary across countries, industries and time periods. Indeed, the trade-investment nexus may be changing as the world's economies become increasingly integrated. Identifying the types of trade and investment policies that are most likely to aid domestic economic performance requires timely evidence on the nature of this relationship for specific countries. The present research offers some recent evidence for a relatively small, open economy that has historically encouraged both international trade and investment flows.

Canada's role and performance within the global economy, as reflected by its trade and investment patterns, is interesting from a number of perspectives. Its experience in the wake of the North American Free Trade Agreement (NAFTA) potentially holds valuable lessons for similar economies that are contemplating their level of involvement in regional trading blocs. In that regard, Canada's heavy reliance on the 
U.S. as its major trading and investment partner is likely to hold implications for other nations that are in a similar position alongside dominant trading partners. Further, outward FDI is of vital importance for countries such as Canada that seek to overcome the limitations of small domestic markets; as such, evidence on the likely impacts of its direct investment abroad would be illuminating. For example, any resultant decline in export activity may add weight to arguments that investment abroad is akin to exporting jobs. Also, there remain a number of unresolved issues surrounding the impacts of increased FDI penetration from the U.S. and elsewhere. Concern over the possibility of negative impacts on domestic industries might prevent policymakers from adopting strategies designed to encourage inbound foreign investment. In turn, this could stifle potential productivity gains for domestic firms achieved via knowledge spillovers. Also, the effect of inward FDI on intra-firm trade and, by extension, the level of exports remains an unsettled issue, and is a major concern here.

The present research analyzes how Canadian exports are affected by both outward and inward stocks of FDI to and from its major trading partners. The empirical methodology examines this relationship for 16 OECD nations, within a framework that considers Canada's unique economic and geographic linkages to the U.S. We focus on exports, rather than total trade volume, because of their important linkages with domestic employment and investment levels. Ultimately, the results generated here may prove valuable to policymakers concerned with identifying which international economic policies are most likely to be conducive to domestic economic growth.

The next section of the paper reviews the pertinent literature, and provides relevant background on other issues. Section III discusses the empirical model, data 
sources, and estimation approach. Next, the empirical results are presented and discussed. A final section summarizes and offers interpretations for our findings.

\section{BACKGROUND LITERATURE}

Previous research has generally been concerned with the potential impact of bilateral FDI on production and investment activities in both host and home countries (Stevens and Lipsey, 1992). The possibility of technology transfers and the resultant productivity gains accruing to domestic firms from inward FDI have served to foster policies to attract such investment. Indeed, some empirical evidence suggests that inward FDI may stimulate domestic investment rather than displace it (Borenzstein and deGregorio, 1995), perhaps owing to the increased competitiveness of domestic firms. Overall, however, the empirical evidence for advanced economies is mixed, mitigating the claim over whether investment inflows are as beneficial as often suggested.

Obviously, from the perspective of the investor (i.e., home) country, an important issue is whether outward FDI substitutes for export activity. It is conceivable that outward FDI stimulates exports from certain industries even as it displaces trade within the industry of the outbound investment. Yet the existing evidence is unclear about the overall effect of outward FDI on investment and trade volume in the home economy. Narrower in scope, our specific concern is with how a country's exports to a trading partner are affected by inward and outward FDI activity with that same country.

Traditional trade theories have been interpreted as implying that exports and outward direct investment are substitutes. Firms are viewed as choosing between production either at home (followed by exports) or abroad (with local sales by their 
foreign affiliates). This decision is articulated as being driven by considerations such as transportation costs and scale economies. This "proximity-concentration tradeoff" is offered to explain why FDI may substitute for trade (Brainard, 1993). An additional argument supporting this view is that multinationals locate subsidiaries near different markets when plant-specific fixed costs are low (Markusen and Venables, 1998). However, if FDI reflects vertical integration whereby firms split production across different countries, then it is conceivable that such investment may actually stimulate trade. The theoretical literature offers only weak guidance on the precise relationship between exports and FDI, especially in view of the role of factors such as tariffs, transport costs, the organization of firm activity, etc. Our understanding of this relationship can be improved by the provision of appropriate empirical evidence.

The existing literature provides some evidence, at the firm level, that outward FDI may stimulate trade volume. Lipsey and Weiss (1984) find a positive relationship between total exports of the parent firm and production levels at affiliate firms. Sachs and Shatz (1994) provide evidence of a complementary relationship between FDI and exports for the U.S., but this may largely reflect the role of intra-firm trade. Additionally, Clausing's (2000) analysis of multinational firms supports a complementary relationship between foreign investment activity (as measured by affiliate sales) and intra-firm trade. Finally, Head and Ries (2001) distinguish between manufacturing vs. distribution affiliates of Japanese multinational firms in finding that the degree of complementarity varies with the importance of intra-firm trade. Their analysis highlights the role of industry characteristics in affecting the magnitude of intra-firm trade. 
Amiti and Wakelin (2003), based on a sample of 36 developed and developing nations, find some evidence of a complementary relationship between exports and investment liberalization. Yet their results indicate that this relationship holds only between partners that are characterized by similar factor endowments and relatively low trading costs. Eaton and Tamura (1994) attempt to explain bilateral trade and FDI flows by relying on traditional gravity model determinants. Their findings suggest, for both the U.S. and Japan, the existence of a large positive relationship between outward FDI and exports and imports alike. An OECD study (1998) estimated import and export equations, and then simulated bilateral trade flows in the absence of FDI for a sample of 21 countries. These results suggest that FDI generally has a positive impact on trade levels, but that the magnitudes of the effect vary dramatically by country. As an example, they find that inward FDI stocks increase exports for the U.K., but not for the U.S. Egger (2001) also reports findings implying that outward investment fails to exhibit a significant positive influence on exports, based on an analysis of $15 \mathrm{EU}$ members over the period 1986-1996. Hejazi and Safarian (2001), using a gravity model linked to the transactions cost theory of multinational enterprises, confirm a complementary relationship between trade and FDI for the U.S. and 51 countries from 1982 to 1994 . Again, their study suggests the need to control for sectoral and/or regional characteristics in order to reflect the different motivations underlying FDI.

Unfortunately, the results of existing empirical efforts tend to vary depending on how investment is measured. Pain and Wakelin (1998), relying on FDI stocks derived for a sample of OECD countries, find that substitution effects were prevalent over the 197192 period. They suggest that the choice of the measure of FDI activity (stocks vs. flows) 
may be pivotal in the nature of the empirical results. Once again, they caution that the trade-investment relationship is likely to vary over time and across countries. Also, many of the economy-wide studies suffer from endogeneity problems because the direction of causality between trade and investment patterns is not straightforward. Fortunately, some of these issues may be resolved by improved empirical designs and appropriate statistical techniques. In sum, the empirical evidence is inconclusive concerning the relationship between foreign investment and trade in general; more specifically, the impact of inward and outward FDI stocks on a country's export activity remains unsettled.

It is clear that a need remains for more recent evidence on the trade-investment nexus, both for the larger industrialized countries and for smaller, open economies. In fact, most of the country-specific evidence is limited to the U.S., Japan, and major European economies. Clearly, this relationship holds important implications for policymakers in smaller nations that have historically embraced international trade and investment flows. Canada is one such country where additional evidence about the effects of FDI is needed to resolve a number of issues. A debate continues over whether inward FDI, particularly from the U.S., will harm Canadian industries and cause a "hollowing out" of their economic sovereignty. The effects of outward FDI on exports and domestic employment remain an unsettled question. Rao, et al (1994) concludes, based on total elasticity estimates from two early sub-periods, that exports (and imports) are complementary to outbound FDI. However, they admit that this result is tentative, citing a need for "more rigorous empirical testing". An ideal approach should control for other trade determinants within the framework of a well-designed regression model.

Canada's economy is strongly oriented towards international investment, with 
bilateral FDI stocks having approximately tripled between 1990 and 2007. Yet it has become a net exporter of capital since the mid-1990s, perhaps owing to its relatively punitive tax system and general restrictions on inbound foreign investment. The importance of both stocks of FDI for Canada, expressed as a percentage of GDP, exceeds the G-7 average (Holden, 2008). Of course, the role of the U.S. as both a source and destination for Canada's FDI is paramount. For 2007, the U.S. represented $57.6 \%$ and $43.9 \%$ of its inward and outward investment stocks respectively. A similar pattern is exhibited for Canada's trade flows, with the U.S. accounting for $73.5 \%$ and $63.7 \%$ of its exports and imports respectively (Foreign Affairs and International trade Canada, 2008). So while it is important to offer new evidence based on recent data for the Canadian economy, an interesting dimension arises when considering that the majority of its tradeinvestment flows pertain to a dominant partner.

\section{METHODOLOGY AND DATA}

\section{Empirical Model}

The primary objective of this study is to clarify the impact of outward and inward FDI on Canadian export flows. Our approach involves estimating statistical relationships that explain variations in Canadian export activity to major OECD countries from 1989 to 2007. The empirical technique is an application of the gravity model, one that is generally consistent with theoretical views of trade and multinational corporations (e.g., see Deardorff, 1998 or Markuses and Venables, 1998). Recent empirical analyses of the trade vs. investment decision often utilize a similar approach (e.g., see Amiti and Wakelin, 2003, Clausing, 2000, or P.J. Smith, 2001). 
In its basic variant, bilateral trade volume between two parties $(i, j)$ depends on individual country characteristics (including per capita income and population) as well as transportation costs and exchange rates. These determinants are incorporated into the following specification:

(1) $\mathrm{T}_{\mathrm{ij}}=\alpha_{0}\left(\mathrm{GDPC}_{\mathrm{i}}\right)^{\alpha 1}\left(\mathrm{POP}_{\mathrm{i}}\right)^{\alpha 2}\left(\mathrm{GDPC}_{\mathrm{j}}\right)^{\alpha .3}\left(\mathrm{POP}_{\mathrm{j}}\right)^{\alpha 4}\left(\mathrm{DIST}_{\mathrm{ij}}\right)^{\alpha 5}\left(\mathrm{REXR}_{\mathrm{ij}}\right)^{\alpha 6}\left(\mathrm{~F}_{\mathrm{j}}\right)^{\alpha 7} \varepsilon_{\mathrm{ij}}$

where $T_{i j}$ is bilateral trade ${ }^{1}$ from $\mathrm{i}$ to $\mathrm{j}$, GDPC is per capita income, POP is population, DIST is geographic distance (as a proxy for transportation costs), and $\mathrm{REXR}_{\mathrm{ij}}$ is the relative exchange rate between the trading partners; $F_{j}$ represents other country-specific factors that might impact the volume of trade flows; $\varepsilon$ is a random disturbance term.

Since our primary concern is with explaining variations in Canadian export activity, we modify (1) by indexing Canada as the source country (i). By relying on panel data, we focus on outward trade in the form of exports (EX) from Canada to specific countries $(j)$ at various points in time $(t)$, obviating the explicit consideration of Canada's population and per capita income in the model. After taking logs, the following static specification includes country fixed effects $\left(F_{j}\right)$ and the stocks of (outward and inward) Canadian direct investment (FDI) to and from each country at each point in time:

(2) $\ln \left(\mathrm{EX}_{\mathrm{jt}}\right)=\mathrm{F}_{\mathrm{j}}+\beta_{1} \ln \mathrm{GDPCjt}+\beta_{2} \ln \mathrm{POPjt}+\beta_{3} \ln \mathrm{REXR}_{\mathrm{jt}}$ $+\beta_{4} \ln \mathrm{INFDI}_{\mathrm{jt}}+\beta_{5} \ln \mathrm{OUTFDI}_{\mathrm{jt}}+\varepsilon_{\mathrm{jt} .}$

\footnotetext{
${ }^{1}$ Some previous empirical work has included affiliate sales and even licensing arrangements (to unaffiliated firms) as part of the total bilateral exchange between countries.
} 
Besides capturing geographic distance, the fixed effects term should also reflect countryspecific influences such as factor endowments, an affiliation with a regional trading bloc, the degree of tariff protection, or trade "resistance"

We specify a dynamic formulation of the model by including the lagged value of exports as an explanatory variable. Further, lagged values for outward and inward FDI are added to capture the linkages between direct investment and export activities (see Egger, 2001). Relying on the fixed effects estimator here may be problematic because the lagged dependent variable is likely to be correlated with the error term. A common approach used with dynamic models is to adopt a first-differenced specification as in:

(3) $\Delta \ln \mathrm{EXP}_{\mathrm{jt}}=\beta_{1} \Delta \ln \mathrm{EXP}_{\mathrm{j}, \mathrm{t}-1}+\beta_{2} \Delta \ln \mathrm{GDPC}_{\mathrm{jt}}+\beta_{3} \Delta \ln \mathrm{POP}_{\mathrm{jt}}+$

$$
\beta_{4} \Delta \ln \text { REXR }_{\mathrm{jt}}+\mathrm{B}_{5} \Delta \ln \mathrm{INFDI}_{\mathrm{j}, \mathrm{t}-1}+\beta_{6} \Delta \ln \mathrm{OUTFDI}_{\mathrm{j}, \mathrm{-}-1}+\varepsilon_{\mathrm{jt}} .
$$

Although this specification eliminates country-specific effects that would otherwise be correlated with the regressors, it also is likely to suffer from endogeneity bias. Arellano and Bond (1991) have popularized a first-differenced estimator that corrects for timeinvariant fixed effects and endogeneity. Accordingly, GMM estimation is useful because these techniques utilize instruments for any endogenous variables. The use of alternative estimators is discussed alongside empirical findings in the following section.

Recall that our major focus is on how Canadian export activity is influenced by inward (and outward) FDI from (to) specific trading partners. Consider the lingering question over whether outward FDI to a specific country displaces exports that would otherwise be sent to that locale. Yet it is conceivable that Canadian direct investment to a specific country $\mathrm{j}\left(\mathrm{OUTFDI}_{\mathrm{j}}\right)$ may actually stimulate exports to that trading partner if

\footnotetext{
${ }^{2}$ Anderson and van Wincoop (2003) have derived a theoretic gravity equation where exports are dependent upon multilateral trade "resistance". Fixed effects estimation may capture such resistance.
} 
there were a corresponding increase in vertical production activities at offshore locales. As such, the sign of the coefficient $\left(\beta_{6}\right)$ for outward FDI is ambiguous.

The model explicitly examines the hypothesis that inward FDI from a specific trading partner tends to stimulate exports to that market as intra-firm trade expands; so a positive coefficient for INFDI $_{\mathrm{j}}$ would confirm this effect. Such a finding may be particularly relevant for Canada in view of the nature of its economic integration with the U.S. As more U.S. affiliates have established operations in Canada, exports to the U.S. have grown. However, empirical evidence is needed to determine whether or not this is a causal relationship.

\section{$\underline{\text { Data Sources }}$}

Efforts to conduct empirical analyses in this area are often hampered by the nature and availability of data sources. For example, FDI stocks at the country-industry level do not typically exist. The approach herein utilizes available foreign investment data for the aggregate economy of Canada, as they pertains to specific trading partners. We employ a time series of FDI "position" data for OECD countries to represent the stock of FDI, generally defined as the book value of assets. As is typically the case with FDI "position" data, there is no distinction made between assets acquired via mergers/acquisitions vs. those generated through "greenfield" investments. These data are provided by the International Direct Investment Statistics Yearbook and Statistics Canada (most recent two years). Data on exports from Canada to individual countries are also available from Statistics Canada. Appendix A provides additional details and sources for these and other remaining variables. Both the export and FDI measures are 
stated in current dollar terms; accordingly we convert these values to constant Canadian dollars by relying on implicit price indexes for exports and investment spending respectively (taken from Statistics Canada).

The index of real effective exchange rates is available from International Financial Statistics published by the International Monetary Fund. Population data and real GDP per capita measures are taken from OECD sources. Also, the OECD's Economic Outlook Database provides information on long-term interest rates. Finally, data on corporate tax rates are constructed from international corporate tax rate surveys conducted by the accounting firm of KPMG, and are available online from the Institute for Fiscal Studies. To sum, the assembled data represents Canada's export and bilateral direct investment activity with 20 major $\mathrm{OECD}^{3}$ nations from 1989 through 2007 . Some of the 340 country-year observations were deleted due to missing data for the FDI stock variables, yielding a panel of 16 countries over 19 years.

\section{EMPIRICAL RESULTS}

The empirical approach tests the sensitivity of results to alternative estimation techniques. Table 1 reports findings based on a one-way (country) fixed effects (FE) estimator for Equation $(2)^{4}$, utilizing the dummy variable approach. The restricted Fvalue for Model I confirms that country-specific attributes exert a significant effect on the

\footnotetext{
${ }^{3}$ Historical FDI stock data is generally incomplete or non-existent for a number of OECD countries, especially those that have been in transition to market economies; accordingly, the analysis here excludes these OECD countries: Czech Republic, Finland, Greece, Hungary, Iceland, Poland, Portugal, Slovakia, and Turkey.

${ }^{4}$ Time effects were shown to be unimportant based on findings from the two-way FE model, and are not reported here.
} 
level of exports shipped from Canada, apart from the influence of the other explanatory variables. Such a finding is not surprising for a variety of reasons. Note that the distance between nations, an important consideration in gravity models as a proxy for transportation costs, is time invariant and is therefore treated here as a country fixed effect. Moreover, other country-specific factors are likely to be operative. These would include an array of cultural, political, and institutional forces that might influence the level of exports to a specific trading partner.

The findings for the static specification in Model I report coefficient values for most variables that are in accordance with hypothesized effects. For example, our results suggest that inward FDI from a specific country tends to have a stimulating effect on exports to that nation. Also, there is no evidence that outward FDI displaces exports to host countries. The coefficient for our exchange rate variable is positive but not statistically significant; this result offers no support for the theoretical view that a strong currency depresses exports ${ }^{5}$. Similar findings related to exchange rates are fairly common in earlier work. One explanation holds that exports may contain high import content (Abeysinghe and Yeok, 1998); this may be especially important as it relates to reexports of goods whose inputs have been sourced from the U.S. Also, Clausing's (2000) analysis of U.S. exports fails to produce conclusive evidence on the impact of exchange rates. Finally, it is possible that this measure may be picking up exchange rate "passthrough", or perhaps is reflective of the high import content of Canadian exports.

\footnotetext{
${ }^{5}$ The choice of how to measure relative exchange rates is critical; we utilize an index of real effective exchange rates for both countries; thus, EXRATE is defined as the ratio of the Canadian value for this index relative to that for each specific country.
} 
In Model II, (one-period) lagged values replace current levels of the FDI variables; the results are quite similar, especially as they pertain to the FDI variables. The final FE model III also includes lagged exports as an explanatory variable. Once again, we find general agreement with the hypothesized effects, and the performance of the FDI variables remains consistent. Of course, these findings may be suspect because the lagged endogenous variable is correlated with the error term. Accordingly, Generalized Method of Moments (GMM) techniques are well-suited for estimating this type of dynamic model.

Following Arellano and Bond (1991), GMM is often employed to address estimation concerns related to endogeneity, fixed effects, and/or non-stationarity problems. This estimator, which is consistent in the absence of serial correlation in the differenced residuals, proceeds by first-differencing the data and using lagged levels as instruments for the (first-differenced) endogenous variables. The basic differenced GMM estimator is fitted to our dynamic Eq.(3); the findings are shown in Table 2 and discussed below.

Results from the two-step differenced GMM estimator are reported in column I. ${ }^{6}$ Despite potential problems when the number of time periods is small, these estimates are considered to be asymptotically efficient. ${ }^{7}$ These findings generally support the hypothesized effects, as well as the primary results implied by the FE model. Notably, the lagged value of inward FDI continues to display a positive and statistically significant

\footnotetext{
${ }^{6}$ Note that the listed variables have been transformed via first-differencing with the GMM estimator.

${ }^{7}$ Results for the single stage estimation are qualitatively similar to those presented here, but with much larger standard errors; this finding is consistent with Arellano and Bond's (1991) suggestion that the twostep method may produce downward biased standard errors when the number of time periods is small. Also, a diagnostic test (Sargan statistic) rejects the validity of the instruments used in the single stage estimation.
} 
impact on Canadian exports. However, the performance of two explanatory variables differs slightly from the FE estimation. Specifically, the coefficient on the exchange rate variable is now negative, a result consistent with theoretical expectations, but remains statistically insignificant. Also, we now observe that the coefficient value for $\ln$ OUTFDI $_{i, t-1}$ is negative, but once again fails to show statistical significance. Thus the impact of outward FDI on exports remains uncertain. Finally, the results here now show that lagged exports do not have a statistically significant effect on current exports. Recall, however, that the previous FE estimator may not be appropriate for the underlying dynamic model since lagged exports represent an endogenous explanatory variable.

The diagnostic tests performed in conjunction with this GMM estimator are supportive of our approach. In contrast to the single-stage results (not reported here), the Sargan test statistic fails to reject the null hypothesis that the instruments are exogenous. Additionally, an autocorrelation test of order two is used to test if the first-difference residuals exhibit second-order serial correlation; we fail to reject the null of no serial correlation in all instances, a finding that corroborates valid instrumentation.

One potential problem with the above estimator is that lagged levels are often poor instruments for first-differences. In fact, the system GMM estimator (Arellano and Bover, 1995) is commonly used to increase efficiency when the data series has a high degree of persistence. The systems approach adds a "levels" equation to the firstdifferenced equation, so that the predetermined and endogenous variables (in levels) are instrumented with lags of their own first differences. We also use two external variables as instruments; specifically, a country's prevailing long-term interest rate (LTIR) and its 
statutory tax rate (STR) are used as exogenous instruments. ${ }^{8}$ For comparison, we apply this system GMM estimator to the model; results are reported in Column II (Table 2).

Although some differences in coefficient values and significance levels emerge from system GMM, the story revealed by the FDI variables remains largely intact. Once again, inward FDI has a stimulative effect on Canadian exports. The impact of outward FDI remains ambiguous however; although there is a sign change in the coefficient value, it remains statistically insignificant. Finally, the difference-Sargan test statistic indicates the validity of the additional instruments used in the systems approach here. ${ }^{9}$ Without regard to which may be the ideal estimator, our findings demonstrate consistency pertaining to the influence of both inward and outward FDI on export activity.

In what follows, we extend the analysis by re-estimating these models after excluding all U.S. observations from the panel data. The rationale for doing this is that the magnitude of Canada's trade and investment flows with the U.S. may produce a distorted view of its international economic relationships with its remaining major trading partners. For comparisons with the full sample results, Columns III and IV report these findings based on the differenced GMM and system GMM estimators respectively.

The findings are generally consistent with those based on the full sample of 16 country observations. Once again, the diagnostic tests confirm the validity of the instruments; specifically, the autocorrelation test statistic and (both) Sargan statistics fail to reject the null hypothesis of serial independence and instrument exogeneity

\footnotetext{
${ }^{8}$ Note that these variables, though not included as regressors in the model, are suitable instruments as they are unlikely to be correlated with the error term but influence levels of foreign direct investment.

${ }^{9}$ Roodman warns that the power of this test is diminished with the use of either "too few" or "too many" instruments, but still advocates its use in distinguishing the system from the difference GMM estimator.
} 
respectively. A comparison of Columns I and II with III and IV shows that the performance of the explanatory variables remains largely unaltered. Interestingly, we continue to observe that (country-specific) inward FDI stimulates export activity. The important implication here for Canada is that export growth driven by inward FDI, perhaps arising from inter-firm trade, is not strictly a phenomenon associated with its dominant trading partner. So the general picture that emerges is that the relationship between Canadian exports and bilateral FDI as it pertains to the U.S. economy is not markedly different from the broader international pattern. One possible exception is noteworthy however. While it is far from conclusive that outward FDI displaces exports to a host economy, the results here suggest that this may be more likely to occur as it pertains to Canada's relationship with trading partners other than the U.S. Note that, when excluding the U.S. data, we observe a negative (and statistically significant in one case) coefficient for the outward stock of FDI. One possible interpretation here is that outward FDI to the U.S. may result in a significant expansion of intra-firm trade between Canada-based firms and their U.S. affiliates. This finding remains speculative however.

\section{SUMMARY AND IMPLICATIONS}

The present research has explored the nature of the relationship between Canadian export activity and direct foreign investment. Our analysis relies on existing data sources, including OECD direct investment statistics that record stocks of both inward and outward FDI from a Canadian perspective. By employing a gravity-type empirical specification, we test for the impact of inward and outward FDI on exports to OECD countries. We consider a number of alternative estimators so that the sensitivity of the 
results pertaining to key variables may be examined; in particular, GMM estimation is utilized to deal with the dynamic nature of the model.

The evidence presented here is interesting, but not provocative, concerning the performance of variables traditionally used to "explain" exports. As expected, per capita GDP generally demonstrates a positive relationship with exports; on the other hand, the impact of relative exchange rates on export activity remains ambiguous. It is conceivable that our exchange rate measure (defined as the ratio of an index of real effective exchange rates $^{10}$ ) may not appropriately capture the "pairwise" exchange rate differentials between Canada and specific trading partners.

But the primary focus of this study concerns the relationship between bilateral FDI and export activity. The evidence presented here demonstrates that inward FDI from a specific source is associated with more exports flowing to that country. This supports the contention that when foreign firms locate in a host economy they often expect this will expand intra-firm trade, as is manifested through export growth. It would be much more difficult, and beyond the scope of this paper, to determine what specific proportion of export growth is attributable to intra-firm trade per se.

The impact of outward FDI on export activity remains more ambiguous. For most of the specifications examined here, Canadian FDI into a host economy (OUTFDI) had no significant effect on exports to that country. A straightforward interpretation of this finding is that Canadian exports do not appear to be displaced by direct investment

\footnotetext{
${ }^{10}$ Recall that real effective exchange rates are constructed by looking at trade-weighted variations in domestic prices and nominal exchange rates; as such, they reflect changes in each country relative to all of its trading partners.
} 
abroad; this implies an increase in intra-firm trade from Canadian firms to their foreign affiliates. However, this finding is tempered somewhat once trade-investment flows with the U.S. are ignored. Now we find some evidence that exports might actually be harmed by outward FDI. Although speculative, this result implies that tariff-jumping could be part of the motivation behind the increase in outward FDI by Canadian firms. Yet the evidence here further implies that this may be less of a motivating factor for direct investment into the U.S., perhaps due to lower tariffs via NAFTA provisions.

The overall impacts of FDI remain inconclusive for several reasons. For one, it is quite possible that outward investment substitutes for exports in certain industries, even as it stimulates trade in others. Clearly, an appropriate level of disaggregation of existing stock or flow data (currently available only for broad sectors of the Canadian economy) is necessary to yield these additional insights. More generally, we urge caution in broadly interpreting our findings. For example, it is easy to speculate that outward foreign investment may be slow in enhancing the international competitiveness of Canadian firms; yet recall that our analysis examines how outward investment affects exports to a specific host economy, not overall exports to all trading partners. Also, our empirical results should not be interpreted as offering support for the notion that inward FDI stimulates total exports as a result of generalized productivity spillovers to the host economy. Nevertheless, the evidence here implies support for policies to dismantle barriers to both inbound and outbound foreign investment. Besides increasing the exposure of domestic firms to global competition, such efforts appear unlikely to shrink the overall level exports from Canada, especially when considering the role of the U.S. economy. 
The findings presented here are suggestive of research initiatives that may further illuminate how globalization trends affect the Canadian economy. For example, the role of intra-firm trade in accounting for export growth holds implications for the open debate on the "hollowing out" of Canadian manufacturing. Also, a fuller exploration of the causal links between bilateral FDI and both imports and exports may be enlightening. 


\section{REFERENCES}

Abeysinghe, T. and T.L. Yeok (1998) "Exchange Rate Appreciation and Export Competitiveness; The Case of Singapore," Applied Economics, Vo.30, pp.51-55.

Amiti, M. and Wakelin, K. (2003) "Investment Liberalization and International Trade," Journal of International Economics, V.61(1). pp.101-26.

Anderson, J.E. and E. van Wincoop (2003) "Gravity with Gravitas: A Solution to the Border Puzzle,” American Economic Review, V.93(1), pp.170-92.

Arellano, M. and S. Bond (1991) "Some Tests of Specification for Panel Data: Monte Carlo Evidence and an Application to Employment Equations," Review of Economic Studies, V.58, pp.277-97.

Blonigen, B.A. (2001) "In Search of Substitution between Foreign Production and Exports," Journal of International Economics, V.58, pp. 81-104.

Borenzstein, E. and J. de Gregorio (1995) "How Does Foreign Direct Investment Affect Economic Growth?”, NBER Working Paper no.5057.

Brainard, S. (1993), “A Simple Theory of Multinational Corporations and Trade with a Trade-off between Proximity and Concentration," NBER Working Paper 4269.

Clausing, K.A. (2000) “Does Multinational Activity Displace Trade?” Economic Inquiry, Vol.38, pp.190-205.

Deardorff, A.V. (1998) "Determinants of Bilateral Trade: Does Gravity Work in the Neoclassical World?" in Frankel, J. (Ed.), Regionalization of the World Economy, NBER, Cambridge, MA, pp.7-31.

Devereaux, M.P. and R. Griffith (2003) "Evaluating Tax Policy for Location Decisions," International Tax and Public Finance, Vol.10, pp.107-26.

Eaton, J. and A. Tamura (1994) "Bilateralism and Regionalism in Japanese and U.S. Trade and Direct Foreign Investment Patterns," Journal of Japanese and International Economics, Vol.8, pp.478-510.

Egger, Peter (2001) "European Exports and Outward Foreign Direct Investment: A Dynamic Panel Data Approach," Weltwirtschaftliches Archiv, Vol.137 (3), pp.427-49.

Falzoni, Anna M. (2000) "Statistics on Foreign Direct Investment and Multinational Corporations: A Survey," paper produced as part of a Research Network on FDI and the 
Multinational Corporation: New Theories and Evidence, funded by the TMR Programme of the European Commission (Contract no.ERBFMRXCT-97-0585).

Fontagne, Lionel (1999) "Foreign Direct Investment and International Trade:

Complements or Substitutes?,"Working paper 1999/3. OECD Directorate for Science, Technology and Industry.

Foreign Affairs and International Trade Canada (2008) "Canada's State of Trade and Investment Update" (www.international.gc.ca/economist).

Feinberg, Susan and Michael Keane (2001) "U.S.-Canada Trade Liberalization and MNC Production Location," Review of Economics and Statistics, Vol.83(1), pp.118-32.

Hejazi, W. and A.E. Safarian (2001) "The Complementarity Between U.S. Foreign Direct Investment Stock and Trade," Atlantic Economic Journal, Vol.29(4), pp.420-437.

Head, K. and J. Ries (2001) "Overseas Investment and Firm Exports," Review of International Economics, Vol.9, pp.108-122.

Holden, Michael (2008) "Overview of Canadian Foreign Direct Investment", Parliamentary Information and Research Service (Library of Parliament), Ottawa, CA.

Hodgson, G. and T. Evans (2003) "The Quiet Creator of Canadian Wealth: Foreign Direct Investment," (Eighth in a Series on Canada and the Global Economy), Export Development Canada, September 2003.

Lipsey, R.E. and M.E. Weiss (1984) "Foreign Production and Exports of Individual Firms," Review of Economics and Statistics, Vol.66(2), pp.304-08.

Markusen, J.R. and A. Venables (1998) "Multinational Firms and the New Trade Theory," Journal of International Economics, Vol. 46(2), pp.183-203.

OECD (1998) "Trade Competition and Foreign Direct Investment: A New Assessment," DSTI/EAS/IND/SWP(98)9, Statistical Working Party of the Industry Committee.

Pain, Nigel and Katharine Wakelin (1998) "Export Performance and the Role of Foreign Direct Investment," The Manchester School Vol.66, no.s (supplement), pp.62-88.

Pantulu, J. and J. Poon (2003) "FDI and International Trade: Evidence from the U.S. and Japan," Journal of Economic Geography, Vol.3, pp.241-59.

Pontes, J.P. (2004) "A Theory of the Relationship Between Foreign Direct Investment and Trade," Economics Bulletin, Vol.6, no.2, pp.1-8. 
Rao, Someshar, Ahmad, Ashfaq, and Marc Legaul (1994) "Canadian Based Multinationals: An Analysis of Activities and Performance," in Globerman, S. (ed.), Canadian Based Multinationals, Industry Canada Research, Ottawa, Canada, pp.63-123.

Roodman, David (2007) "A Short Note on the Theme of Too Many Instruments," Center for Global Development, Working Paper No.125 (August).

Sachs, J.D. and H.D. Shatz (1994) "Trade and Jobs in U.S. Manufacturing,” Brookings Papers on Economic Activity, Vol.1, pp.1-69.

Smith, P.J. (2001) "How do foreign patent rights affect U.S. exports, affiliate sales, and licenses?," Journal of International Economics, Vol.55, pp.411-39.

Stevens,G. and R.E. Lipsey (1992) "Interactions Between Domestic and Foreign Investment," Journal of International Money and Finance, Vol.11(1), pp.40-62. 
Appendix A - Data Sources and Definitions

\begin{tabular}{|c|c|c|}
\hline Variable & Definition & Source \\
\hline 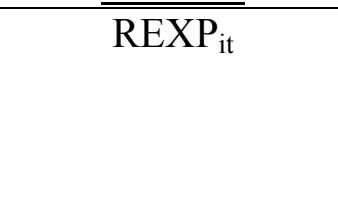 & $\begin{array}{l}\text { Real Exports ( in constant } \\
\text { Cdn. \$) to country } j \text { at time } t\end{array}$ & $\begin{array}{c}\text { Strategis website } \\
\text { (www.strategis.ca); } \\
\text { CANSIM Table } \\
\text { No.2270001 }\end{array}$ \\
\hline OUTFDI $_{\mathrm{it}}, \mathrm{INFDI}_{\mathrm{it}}$ & $\begin{array}{c}\text { Outward and Inward stocks } \\
\text { of FDI (in constant Cdn. \$) } \\
\text { to/from country } i \text { at time t }\end{array}$ & $\begin{array}{l}\text { www.dfait-maeci.gc.ca/eet; } \\
\text { International Direct } \\
\text { Investment Statistics } \\
\text { Yearbook, } 2008 \text { ed., } \\
\text { OECD, Paris, 2009; } \\
\text { CANSIM Table } \\
\text { No.3760051 }\end{array}$ \\
\hline EXRATE $_{\text {it }}$ & $\begin{array}{l}\text { Real Exchange Rate Index } \\
\text { for country } i \text { at time } t\end{array}$ & $\begin{array}{l}\text { International Monetary } \\
\text { Fund, IFS Online } \\
\text { (http://ifs.apdi.net/imf/) }\end{array}$ \\
\hline $\mathrm{POP}_{\text {it }}$ & $\begin{array}{l}\text { Population of country } i \text { at } \\
\text { time } t\end{array}$ & http://www.oecd.org \\
\hline $\mathrm{DIST}_{\mathrm{i}}$ & $\begin{array}{c}\text { Distance }(\mathrm{km}) \text { to } \\
\text { national capital city }\end{array}$ & www.eiit.org/ \\
\hline $\mathrm{GDPC}_{\text {it }}$ & $\begin{array}{l}\text { Real }^{*} \text { GDP per capita } \\
\text { (in US \$) }\end{array}$ & $\begin{array}{c}\text { World Economic Outlook } \\
\text { Database, September 2009; } \\
\text { http://www.imf.org/ }\end{array}$ \\
\hline $\mathrm{IR}_{\mathrm{it}}$ & $\begin{array}{l}\text { Long-term interest rate } \\
\text { in country } i \text { at time } t\end{array}$ & $\begin{array}{l}\text { OECD StatExtracts, derived } \\
\text { from OECD Economic } \\
\text { Outlook, Nov.2008 }\end{array}$ \\
\hline TAXR $_{\text {it }}$ & $\begin{array}{l}\text { Statutory corporate tax rate } \\
\text { in country } i \text { at time } t\end{array}$ & $\begin{array}{l}\text { KPMG Corporate Tax Rate } \\
\text { Survey (various issues); } \\
\text { Institute for Fiscal Studies } \\
\text { www.ifs.org.uk }\end{array}$ \\
\hline
\end{tabular}

${ }^{*}$ Current US \$ values converted into constant \$ terms via each country's GDP deflator (also from IMF's World Economic Outlook, Sept. 2008). 
TABLE 1-Fixed Effects Estimation

[Dependent variable $\left.=\ln \mathrm{REXP}_{\mathrm{it}}\right]^{\mathrm{a}}$

$\begin{array}{llll}\text { Model: } & \text { I } & \text { II } & \text { III }\end{array}$

\begin{tabular}{|c|c|c|c|}
\hline Constant & -6.66835 & -9.3571 & -8.80503 \\
& $(1.01)$ & $(1.40)$ & $(1.35)$ \\
\hline $\ln \mathrm{GDPC}_{\mathrm{it}}$ & $0.796856^{*}$ & $0.8004^{*}$ & $0.760365^{*}$ \\
& $(6.55)$ & $(6.46)$ & $(6.26)$ \\
\hline $\ln \mathrm{POP}_{\mathrm{it}}$ & 0.752223 & $0.992885^{* * *}$ & 0.867625 \\
& $(1.29)$ & $(1.70)$ & $(1.52)$ \\
\hline $\ln \mathrm{EXRATE}_{\mathrm{it}}$ & 0.107718 & 0.083052 & -0.02584 \\
& $(0.78)$ & $(0.60)$ & $(0.19)$ \\
\hline $\ln$ OUTFDI $_{\mathrm{it}}$ & 0.035955 & ------ & ------ \\
& $(1.56)$ & ------ & ------- \\
\hline $\ln$ INFDI $_{\mathrm{it}}$ & $0.075236^{* *}$ & & \\
\hline $\ln \mathrm{REXP}_{\mathrm{i}, \mathrm{t}-1}$ & $(2.40)$ & ------- & $0.131291^{*}$ \\
& ------ & $(4.14)$ \\
\hline $\ln$ OUTFDI $_{\mathrm{i}, \mathrm{t}-1}$ & ------- & 0.025992 & 0.022884 \\
& & $(1.19)$ & $(1.08)$ \\
\hline $\ln$ INFDI $_{\mathrm{i}, \mathrm{t}-1}$ & ------- & $0.055432^{* * *}$ & 0.046653 \\
& & $(1.76)$ & $(1.51)$ \\
\hline $\mathrm{R}^{2}$ & .976 & .975 & .977 \\
\hline \# observations & 304 & 304 & 304 \\
\hline $\mathrm{F}^{*}$ value & $96.79^{*}$ & $96.73^{*}$ & $32.05^{*}$ \\
\hline
\end{tabular}

${ }^{a}$ numbers in parentheses are absolute values of t-statistics;

$*, * *, * * *$ indicate statistically significance at the $1 \%, 5 \%$, and $10 \%$ level respectively. 
TABLE 2-Export Demand Equations $\$$

$\left[\text { Dependent variable }=\ln \mathrm{REXP}_{\mathrm{it}}\right]^{\$ \$}$

$\begin{array}{cccc}\text { I } & \text { II } & \text { III } & \text { IV } \\ \text { GMM-DIFF } & \text { GMM-SYS } & \begin{array}{c}\text { GMM-DIFF } \\ \text { (excludes US) }\end{array} & \begin{array}{c}\text { GMM-SYS } \\ \text { (excludes US) }\end{array}\end{array}$

\begin{tabular}{|c|c|c|c|c|}
\hline Constant & $\begin{array}{c}0.04467^{* *} \\
(2.09)\end{array}$ & $\begin{array}{c}0.007303 \\
(0.82) \\
\end{array}$ & $\begin{array}{c}.023934 \\
(1.09) \\
\end{array}$ & $\begin{array}{l}.00744 \\
(0.88)\end{array}$ \\
\hline $\ln \mathrm{GDPC}_{\mathrm{it}}$ & $\begin{array}{c}0.626055^{*} \\
(3.82)\end{array}$ & $\begin{array}{c}-0.03669 \\
(1.39) \\
\end{array}$ & $\begin{array}{c}0.702833^{*} \\
(4.17)\end{array}$ & $\begin{array}{c}-0.00687 \\
(0.14)\end{array}$ \\
\hline $\ln \mathrm{POP}_{\mathrm{it}}$ & $\begin{array}{c}-2.18818 \\
(1.02)\end{array}$ & $\begin{array}{c}0.118728^{* *} \\
(2.36)\end{array}$ & $\begin{array}{c}-0.1763 \\
(0.10)\end{array}$ & $\begin{array}{c}0.237263^{*} \\
(2.74)\end{array}$ \\
\hline ln EXRATE $_{\text {it }}$ & $\begin{array}{c}-0.22077 \\
(1.01)\end{array}$ & $\begin{array}{c}0.237396^{*} \\
(2.79)\end{array}$ & $\begin{array}{c}-0.31012 \\
(1.00)\end{array}$ & $\begin{array}{c}0.359353^{*} \\
(2.75)\end{array}$ \\
\hline In $\mathrm{REXP}_{\mathrm{i}, \mathrm{t}-1}$ & $\begin{array}{c}0.13244 \\
(0.79)\end{array}$ & $\begin{array}{c}0.73901^{*} \\
(11.18)\end{array}$ & $\begin{array}{c}0.141121 \\
(0.81)\end{array}$ & $\begin{array}{c}0.547203^{*} \\
(7.08)\end{array}$ \\
\hline $\ln$ OUTFDI $_{\mathrm{i}, \mathrm{t}-1}$ & $\begin{array}{c}-0.04842 \\
(0.66)\end{array}$ & $\begin{array}{c}0.002097 \\
(0.07)\end{array}$ & $\begin{array}{c}-0.2180^{* * * *} \\
(1.72)\end{array}$ & $\begin{array}{c}-0.01667 \\
(0.31)\end{array}$ \\
\hline $\ln \mathrm{INFDI}_{\mathrm{i}, \mathrm{t}-1}$ & $\begin{array}{c}0.180267^{* *} \\
(2.27) \\
\end{array}$ & $\begin{array}{c}0.143433^{*} \\
(3.19) \\
\end{array}$ & $\begin{array}{c}0.153468^{* *} \\
(2.29) \\
\end{array}$ & $\begin{array}{c}0.139433^{*} \\
(2.97) \\
\end{array}$ \\
\hline & & & & \\
\hline Sargan & $\begin{array}{c}6.69 \\
{[>1.00]}\end{array}$ & $\begin{array}{c}28.98 \\
{[>1.00]}\end{array}$ & $\begin{array}{c}8.21 \\
{[>1.00]}\end{array}$ & $\begin{array}{c}27.65 \\
{[>1.00]}\end{array}$ \\
\hline Sargan-diff & N.A. & $\begin{array}{c}22.29 \\
{[>1.00]}\end{array}$ & N.A. & $\begin{array}{c}19.44 \\
{[>1.00]}\end{array}$ \\
\hline
\end{tabular}

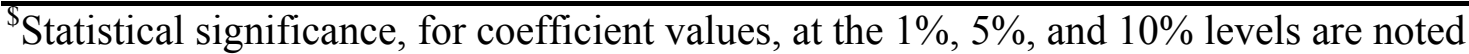
by *,**, and *** respectively; numbers in parentheses () are absolute values of $\mathrm{t}$ statistics. Numbers reported in square brackets [ ] are p-values for diagnostic tests. ${ }^{\$ S}$ All variables are transformed into first differences via the GMM technique; note that "system" GMM includes "levels" equations stacked with those based on first differences alone.
} 